\title{
Reef fish community structure on three islands of Itaipu, Southeast Brazil
}

\author{
José Policarpo de Mendonça-Neto, Cassiano Monteiro-Neto and Luiz Eduardo Moraes
}

We provide here the first assessment of the composition, abundance and distribution of rocky reef fishes of Itaipu Sound, Rio de Janeiro, off the southeastern Brazilian coast. Monthly visual censuses, benthic quadrats and chain link transects were conducted over one year on rocky reefs at three islands (Menina, Mãe and Pai). A total of 2466 individual fish, belonging to 29 families and 42 species were recorded. The most abundant fish species were Parablennius pilicornis, Haemulon steindachneri, Orthopristis ruber and Diplodus argenteus. Sheltered and complex habitats showed the most abundant and diverse fish populations. There was a major significant separation between sampling sites and a secondary seasonal pattern. The three sites showed similar fish communities with locally structured environmental gradients according to their inherent habitat characteristics.

Apresentamos aqui o primeiro estudo da composição, abundância e distribuição de peixes recifais nos recifes rochosos da enseada de Itaipu, Rio de Janeiro, Brasil. Foram realizados mensalmente censos visuais, quadrats de composição bentônica e transectos com correntes durante um ano em recifes rochosos de três ilhas (Menina, Mãe e Pai). Um total de 2466 peixes pertencentes a 29 famílias e 42 espécies foi registrado. Os peixes mais abundantes foram Parablennius pilicornis, Haemulon steindachneri, Orthopristis ruber e Diplodus argenteus. Os recifes mais abrigados e com maior complexidade de hábitats foram os que apresentaram maior abundância e diversidade de espécies. Análises estatísticas revelaram distinções significativas entre as áreas amostradas e um padrão sazonal secundário. As três áreas apresentaram basicamente a mesma comunidade de peixes, estruturadas a partir de gradientes ambientais e de características estruturais próprias de cada ilha.

Key words: Rocky reef fishes, Habitat complexity, Benthic biota.

\section{Introduction}

Most studies about the community ecology of Brazilian reef fishes began in the late 1990s, and applied underwater visual census techniques (Rosa \& Moura, 1997; Rocha et al., 1998; Ferreira et al., 1998; Rocha \& Rosa, 2001). These studies were conducted at several sites throughout the tropical and subtropical Brazilian coastline, from below the mouth of the Amazon River at the Manuel Luiz Reefs ( $0^{\circ} 52$ ' S) (Rocha \&

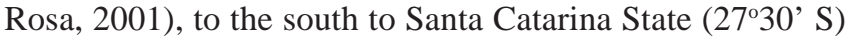
(Floeter et al., 2001).

On the southeastern Brazilian coastline, rocky shores comprise the habitat for reef fishes and other reef-associated biota (Floeter et al., 2004; Rangel et al., 2007). Despite an overall lower complexity when compared to coral reefs, rocky reefs are characterized by a high fish diversity and endemism (Ferreira et al., 2001; Rocha, 2003). Considering the continental dimension of the Brazilian coast (almost $8000 \mathrm{~km}$ ), a limited set of scientific works on the ecology and community struc- ture of reef fishes is currently available.

Differences in reef fish communities can be found along geographic gradients (Parrish, 1989; Sale, 1991; Joyeux et al., 2001) and distinct reef types (Ebeling \& Hixon, 1991; Ferreira et al., 2001; Bellwood \& Wainwright, 2002). Patterns of occurrence and distribution of these assemblages often vary over space and time, influenced by a set of integrated physical and biological factors (McCormick, 1989; Syms \& Jones, 2000; Acosta \& Robertson, 2002). Wave exposure, water depth and topographic complexity may exert variable degrees of interference upon many ecological processes, such as recruitment, predation and territoriality (Caley, 1993; Cheney \& Côté, 2003; Kawasaki et al., 2003).

In this work, we analyzed reef fish community variation over space and time on three islands in Itaipu Sound, Rio de Janeiro, Brazil. We studied changes in species composition, abundance and diversity and their correlation with benthic coverage and habitat complexity. 


\section{Materials and Methods}

\section{Study Site.}

This study was carried out on three islands of Itaipu Sound, Niterói, RJ, Brazil (2258’S; 4302’W) from April 2002 to March 2003. Menina Island, Mãe Island and Pai Island are, respectively, $1 \mathrm{~km}, 2.5 \mathrm{~km}$ and $4.2 \mathrm{~km}$ off the Brazilian coast. Pai Island is the farthest and most exposed study site. We selected one sampling station located on the sheltered face of each island (Fig. 1). This selection was based on water visibility and diving conditions which could enable surveys to be conducted throughout the year.

\section{Environmental variables and benthic biota.}

At each site, we measured water visibility (Secchi disk), water temperature at diving depth $\left({ }^{\circ} \mathrm{C}\right.$, mercury thermometer) and site rugosity using the chain method (Luckhurst \& Luckhurst, 1978) as an index of habitat complexity. Benthic organisms were pooled into ecological and morpho-functional groups: grazers (black and purple sea urchins), sessile constructive (mussels, oyster and barnacles), mobile (gastropoda, sea cucumbers and star fish) and sessile (anemones, turf algae and bryozoans). Individual counts and percent coverage were conducted on replicate $1-\mathrm{m}^{2}$ aluminum squares (quadrats) at different points within the same area where visual censuses for reef fishes were performed.

\section{Reef fish community.}

Reef fish community was assessed through $20 \mathrm{~m} \times 2 \mathrm{~m}$ underwater strip transects $\left(40 \mathrm{~m}^{2}\right)$, varying from the shallowest zones to the bottom rocky/sand interface, about 6-9 meters deep. All sites were visited once a month, and censuses were conducted within the same day between 8:00 and 12:00, starting at Pai Island and finishing at Menina Island. We conducted a total of 108 transects, 36 on each site. Fish counts were conducted in a slow constant swimming velocity (Russ \& Gladstone, 1990) and performed by the same observer (J. P. Mendonça-Neto). Sighted fishes were identified and counted,

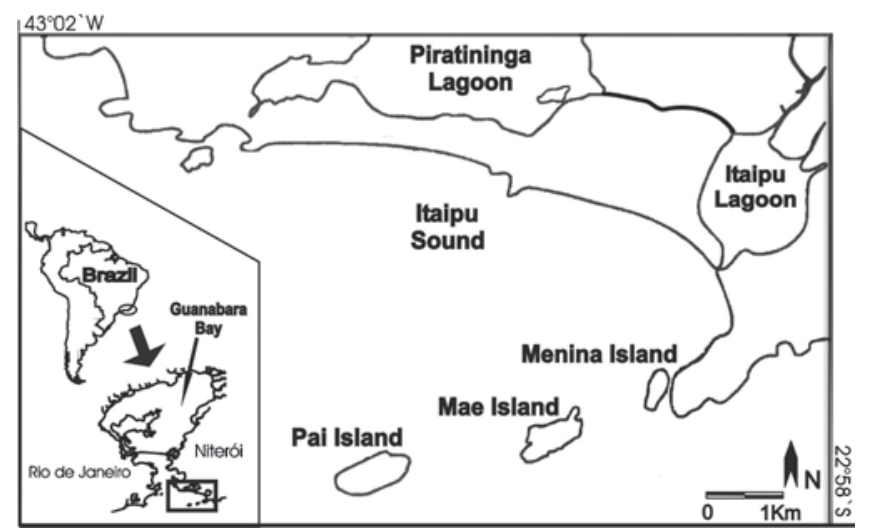

Fig. 1. Map of Itaipu Sound, showing the three study sites: Menina, Mãe and Pai Islands. Inset represents the geographical location of Itaipu Sound in relation to Guanabara Bay and the Rio de Janeiro coast within Brazil. and the information was recorded on a PVC plate (Williams, 1982). Afterwards, fish count data were expressed as frequency of occurrence and relative abundance.

\section{Statistical analysis.}

Renyi's graphic ordination method was used to check if species diversity was comparable between sites (Hill, 1973; Legendre \& Legendre, 1998). According to the method, when diversity patterns are parallel to each other, species diversity may be compared, but when diversity patterns cross each other, no comparisons are possible. Differences among average diversity were statistically tested with bootstrapping following the model proposed by Solow (1993). The Species Diversity \& Richness v.2.3 software was used for all procedures (Henderson \& Seaby, 1998).

Multivariate analysis of the data including non-metric multidimensional scaling (nMDS) and analysis of similarities (ANOSIM) was performed with PRIMER 5 software (Primer-E 2000). Both procedures used a Bray-Curtis similarity matrix. MDS is a 3-dimensional ordination of samples brought down to a 2-dimensional plot. The quality of the plot is indicated by its stress value: values $<0.2$ give a potentially useful 2 -dimensional picture, stress $<0.1$ corresponds to a good ordination, and stress $<0.05$ is an excellent representation. The ANOSIM significance test compares similarities between species by sample matrices. The global $\mathrm{R}$ indicates the degree of similarity between the tested groups, with values between -1 and 1 . If all replicates within sites are more similar to each other than any replicate from different sites, the value of $\mathrm{R}$ is 1 ; values close to zero indicate that the similarity between sites is very high. A two-way crossed analysis of ANOSIM was performed with the original data, where no transformation or standardization was conducted (Clarke \& Warwick, 1994).

The relationship between fish community and environmental variables (water visibility, temperature, bottom complexity and benthic coverage) was investigated by canonical correspondence analysis (CCA) (Legendre \& Legendre, 1998). The primary matrix consisted of abundance data of fish species (row) per sample (column), and the secondary matrix environmental consisted of data including the variables previously mentioned and the relative abundance of benthic coverage data. Monte Carlo permutation tests were employed to determine the statistical significance of the main correlations, and their relative contribution to the final model. Only statistically significant variables were maintained. A similar procedure was applied to determine the statistical significance of the first four canonical axes. This analysis was entirely performed on CANOCO for Windows 4.0 (ter Braak \& Smilauer, 1998).

\section{Results}

A total of 2446 fishes from 29 families and 42 species were recorded through visual censuses at the three sites during the survey (Tab. 1). Parablennius pilicornis was the most abundant species in all sites pooled, followed by Haemulon 
Table 1. Fish families, species, symbols, number of individuals (n) and relative abundance (\%) at each site (Pai, Mãe, and Menina Islands) and pooled for all sites (Total).

\begin{tabular}{|c|c|c|c|c|c|c|c|c|c|c|c|}
\hline \multirow[b]{2}{*}{ Family } & \multirow[b]{2}{*}{ Species } & \multirow[b]{2}{*}{ Symbol } & \multicolumn{2}{|c|}{ Pai Island } & \multicolumn{2}{|c|}{ Mãe Island } & \multicolumn{2}{|c|}{ Menina Island } & \multicolumn{3}{|c|}{ Total } \\
\hline & & & $\mathrm{n}$ & $\%$ & $\mathrm{n}$ & $\%$ & $\mathrm{n}$ & $\%$ & nT & $\% \mathrm{~T}$ & $\% \mathrm{~F}$ \\
\hline Acanthuridae & Acanthurus chirurgus & ACACHI & 5 & 0.65 & 11 & 1.03 & 8 & 1.26 & 24 & 0.97 & 22.2 \\
\hline Ariidae & Bagre spp. & BAGSPP & 0 & 0.00 & 4 & 0.38 & 0 & 0.00 & 4 & 0.16 & 5.6 \\
\hline Belonnidae & Hemiramphus spp. & HEMSPP & 0 & 0.00 & 9 & 0.85 & 0 & 0.00 & 9 & 0.36 & 8.3 \\
\hline Blennidae & Parablennius pilicornis & PARPIL & 147 & 19.09 & 182 & 17.12 & 159 & 25.12 & 488 & 19.79 & 80.5 \\
\hline Blennidae & Scartella cristata & SCACRI & 25 & 3.25 & 10 & 0.94 & 8 & 1.26 & 43 & 1.74 & 52.7 \\
\hline Blennidae & Parablennius spp. & PARSPP & 6 & 0.78 & 3 & 0.28 & 1 & 0.16 & 10 & 0.41 & 13.8 \\
\hline Bothidae & Bothus ocellatus & BOTOCE & 0 & 0.00 & 11 & 1.03 & 0 & 0.00 & 11 & 0.45 & 16.6 \\
\hline Carangidae & Caranx spp. & CARSPP & 1 & 0.13 & 2 & 0.19 & 30 & 4.74 & 33 & 1.34 & 8.3 \\
\hline Carangidae & Pseudocaranx dentex & PSEDEN & 5 & 0.65 & 5 & 0.47 & 0 & 0.00 & 10 & 0.41 & 16.6 \\
\hline Chaetodontidae & Chaetodon striatus & CHASTR & 16 & 2.08 & 45 & 4.23 & 41 & 6.48 & 102 & 4.14 & 80.5 \\
\hline Chaetodontidae & Chaetodon sedentarius & CHASED & 0 & 0.00 & 0 & 0.00 & 3 & 0.47 & 3 & 0.12 & 2.8 \\
\hline Dactylopteridae & Dactylopterus volitans & DACVOL & 41 & 5.32 & 66 & 6.21 & 44 & 6.95 & 151 & 6.12 & 86.1 \\
\hline Diodontidae & Chylomicterus spinosus & CHYSPI & 5 & 0.65 & 21 & 1.98 & 0 & 0.00 & 26 & 1.05 & 36.1 \\
\hline Diodontidae & Diodon hystrix & DIOHYS & 0 & 0.00 & 0 & 0.00 & 1 & 0.16 & 1 & 0.04 & 2.8 \\
\hline Gerreidae & Eucinostomus spp. & EUCSPP & 7 & 0.91 & 9 & 0.85 & 0 & 0.00 & 16 & 0.65 & 13.8 \\
\hline Haemulidae & Haemulon steindachneri & HAESTE & 131 & 17.01 & 77 & 7.24 & 61 & 9.64 & 269 & 10.91 & 83.3 \\
\hline Haemulidae & Orthopristis ruber & ORTRUB & 119 & 15.45 & 74 & 6.96 & 67 & 10.58 & 260 & 10.54 & 86.1 \\
\hline Haemulidae & Anisotremus virginicus & ANIVIR & 5 & 0.65 & 1 & 0.09 & 0 & 0.00 & 6 & 0.24 & 13.8 \\
\hline Holocentridae & Myriprists jacobus & MYRJAC & 0 & 0.00 & 2 & 0.19 & 0 & 0.00 & 2 & 0.08 & 2.8 \\
\hline Labridae & Halichoeres poeyi & HALPOE & 6 & 0.78 & 38 & 3.57 & 2 & 0.32 & 46 & 1.87 & 41.6 \\
\hline Labridae & Halichoeres dimidiatus & HALDIM & 0 & 0.00 & 9 & 0.85 & 0 & 0.00 & 9 & 0.36 & 8.3 \\
\hline Labrisomidae & Labrisomus nuchipinnis & LABNUC & 1 & 0.13 & 14 & 1.32 & 7 & 1.11 & 22 & 0.89 & 38.8 \\
\hline Labrisomidae & Malacoctenus spp. & MALSPP & 0 & 0.00 & 0 & 0.00 & 4 & 0.63 & 4 & 0.16 & 2.8 \\
\hline Lutjanidae & Lutjanus spp. & LUTSPP & 0 & 0.00 & 6 & 0.56 & 3 & 0.47 & 9 & 0.36 & 11.1 \\
\hline Monacanthidae & Stephanolepis hispidus & STEHIS & 57 & 7.40 & 54 & 5.08 & 37 & 5.85 & 148 & 6.00 & 88.8 \\
\hline Mullidae & Pseudupeneus maculatus & PSEMAC & 11 & 1.43 & 32 & 3.01 & 6 & 0.95 & 49 & 1.99 & 47.2 \\
\hline Muraeneidae & Gymnothorax spp. & GYMSPP & 0 & 0.00 & 5 & 0.47 & 0 & 0.00 & 5 & 0.20 & 8.3 \\
\hline Pomacanthidae & Pomacanthus paru & POMPAR & 0 & 0.00 & 4 & 0.38 & 1 & 0.16 & 5 & 0.20 & 11.1 \\
\hline Pomacentridae & Abudefduf saxatilis & ABUSAX & 29 & 3.77 & 91 & 8.56 & 2 & 0.32 & 122 & 4.95 & 52.7 \\
\hline Pomacentridae & Chromis multilineata & CHRMUL & 38 & 4.94 & 26 & 2.45 & 3 & 0.47 & 67 & 2.72 & 41.6 \\
\hline Pomacentridae & Stegastes fuscus & STEFUS & 1 & 0.13 & 4 & 0.38 & 21 & 3.32 & 26 & 1.05 & 25.0 \\
\hline Priacanthidae & Heteropriacanthus cruentatus & HETCRU & 0 & 0.00 & 2 & 0.19 & 0 & 0.00 & 2 & 0.08 & 2.8 \\
\hline Scaridae & Sparisoma axillare & SPAAXI & 0 & 0.00 & 8 & 0.75 & 0 & 0.00 & 8 & 0.32 & 11.1 \\
\hline Scianidae & Pareques acuminatus & PARACU & 12 & 1.56 & 24 & 2.26 & 2 & 0.32 & 38 & 1.54 & 44.4 \\
\hline Scorpaenidae & Scorpaena spp. & SCOSPP & 0 & 0.00 & 1 & 0.09 & 1 & 0.16 & 2 & 0.08 & 5.6 \\
\hline Serranidae & Mycteroperca acutirostris & MYCACU & 10 & 1.30 & 22 & 2.07 & 3 & 0.47 & 35 & 1.42 & 50.0 \\
\hline Serranidae & Epinephelus marginatus & EPIMAR & 4 & 0.52 & 21 & 1.98 & 3 & 0.47 & 28 & 1.14 & 36.1 \\
\hline Sparidae & Diplodus argenteus & DIPARG & 62 & 8.05 & 88 & 8.28 & 49 & 7.74 & 199 & 8.07 & 83.3 \\
\hline Sparidae & Pagrus pagrus & PAGPAG & 0 & 0.00 & 6 & 0.56 & 0 & 0.00 & 6 & 0.24 & 2.8 \\
\hline Synodontidae & Synodus spp. & SYNSPP & 0 & 0.00 & 4 & 0.38 & 1 & 0.16 & 5 & 0.20 & 11.1 \\
\hline Tetraodontidae & Sphoeroides spengleri & SPHSPE & 26 & 3.38 & 66 & 6.21 & 65 & 10.27 & 157 & 6.37 & 83.3 \\
\hline Tetraodontidae & Sphoeroides greeleyi & SPHGRE & 0 & 0.00 & 6 & 0.56 & 0 & 0.00 & 6 & 0.24 & 8.3 \\
\hline Total & & & 770 & 100 & 1063 & 100 & 633 & 100 & 2466 & 100 & \\
\hline
\end{tabular}

Table 2. Summary of fish community (means \pm standard deviation), habitat complexity and benthic composition (relative percent abundance) plus ANOVA results among sites. * Significant difference.

\begin{tabular}{lccccc}
\hline & Pai $(\mathrm{P})$ & Mãe $(\mathrm{M})$ & Menina $(\mathrm{Me})$ & & \\
\cline { 2 - 6 } Fish species richness (species per census) & $11 \pm 7.7$ & $19 \pm 6.3$ & $10 \pm 4.9$ & $\mathrm{p}<0.05^{*}$ & $\mathrm{M} \neq \mathrm{P}=\mathrm{Me}$ \\
Total number of fishes per census & $64 \pm 4$ & $88 \pm 7.6$ & $53 \pm 4.9$ & $\mathrm{p}<0.01^{*}$ & $\mathrm{M} \neq \mathrm{P}=\mathrm{Me}$ \\
Habitat complexity (chain link rugosity index) & $1.24 \pm 0.1$ & $1.36 \pm 0.09$ & $1.17 \pm 0.17$ & $\mathrm{p}<0.05^{*}$ & $\mathrm{M} \neq \mathrm{P}=\mathrm{Me}$ \\
GRAZERS & $\%$ & $\%$ & $\%$ & & \\
Black sea urchin - Echinometra lucunter & 29.3 & 9.4 & 31.2 & $\mathrm{p}<0.05^{*}$ & $\mathrm{M} \neq \mathrm{P}=\mathrm{Me}$ \\
Purple sea urchin - Litechinus variegatus & 15.2 & 10.9 & 13.7 & $\mathrm{p}=0.2$ & $\mathrm{M}=\mathrm{P}=\mathrm{Me}$ \\
SESSILE CONSTRUCTIVE & & & & & \\
Mussel - Perna perna & 3.8 & 5.6 & 22.1 & $\mathrm{p}<0.01^{*}$ & $\mathrm{M}=\mathrm{P} \neq \mathrm{Me}$ \\
Oyster - Crassostrea spp. & 2.9 & - & 13.1 & $\mathrm{p}<0.05^{*}$ & $\mathrm{M} \neq \mathrm{P} \neq \mathrm{Me}$ \\
Barnacle - Balanus spp. & 3.1 & 5.7 & 5.2 & $\mathrm{p}<0.01^{*}$ & $\mathrm{M}=\mathrm{P}=\mathrm{Me}$ \\
MOBILE & 0.6 & 14.3 & - & $\mathrm{p}<0.01^{*}$ & $\mathrm{M} \neq \mathrm{P}=\mathrm{Me}$ \\
Sea cucumber - Isosthicopus badionatus & 3.1 & 1.8 & - & $\mathrm{p}=0.72$ & $\mathrm{M} \neq \mathrm{P} \neq \mathrm{Me}$ \\
Star fish - Echinaster brasiliensis & 2.3 & 2.9 & - & $\mathrm{p}=0.48$ & $\mathrm{M}=\mathrm{P} \neq \mathrm{Me}$ \\
Sessile invertebrates - Gastropoda & & & & & \\
SESSILE & 9.1 & 7.3 & 1.6 & $\mathrm{p}<0.01^{*}$ & $\mathrm{M}=\mathrm{P} \neq \mathrm{Me}$ \\
Anemone - Bunudosoma caissarum & 30 & 39.1 & 12.7 & $\mathrm{p}=0.07$ & $\mathrm{M}=\mathrm{P} \neq \mathrm{Me}$ \\
Turf algae & 0.6 & 3 & - & $\mathrm{p}=0.05^{*}$ & $\mathrm{M} \neq \mathrm{P}=\mathrm{Me}$ \\
Bryozoan - Schizophorella spp. & & & &
\end{tabular}


steindachneri, Orthopristis ruber and Diplodus argenteus. Together, they comprised $49 \%$ of the total number of fishes recorded. Stephanolepis hispidus was the most frequent species at all sites, followed by Dactylopterus volitans and Orthopristis ruber. The three sites sustained basically the same community of fish species, despite differences in abundance (Table 1). Fish species richness and total number of fishes per census were significantly higher at Mãe than at the Pai and Menina sites (Table 2). Reyni's diversity showed that Mãe reached a significantly higher diversity when compared with Menina and Pai Islands (Fig. 2).

A total of 770 fishes belonging to 25 species of 17 families were sighted at Pai Island. The top three species in terms of relative abundance were Parablennius pilicornis, Haemulon steindachneri and Orthopristis ruber. Together they represented $51 \%$ of all observations (Table 1). This site was characterized by a mean water visibility of $5.7 \mathrm{~m}$ and low habitat complexity; the greatest proportion of the benthic community was represented by grazers and turf algae (Table 2).

At Mãe Island, a total of 1063 fishes from 39 species and 27 families were recorded. Parablennius pilicornis, Abudefduf saxatilis and Diplodus argenteus were the most abundant species, totaling $34 \%$ of the local abundance (Table 1). This site showed the best water visibility, varying between 6 and $12 \mathrm{~m}$, and the highest habitat complexity. Turf algae and gastropod mollusks had the greatest abundance among members of the benthic community (Table 2).

Menina Island showed intermediate species richness and the lowest overall abundance (633 fishes from 28 species and 21 families). Parablennius pilicornis, Orthopristis ruber and the Sphoeroides spengleri were the most abundant species and accounted for $46 \%$ of the total sightings at this site (Tab. 1). Menina Island was characterized by the lowest water visibility, with a mean of $4.6 \mathrm{~m}$, often at the technical limits for visual census, and lowest habitat complexity. Grazers and sessile constructive organisms dominated the benthic community (Table 2).

Multidimensional scaling revealed an apparent pattern of separation between sampling sites, with Mãe clearly differing from both Pai and Menina Islands. A secondary seasonal pattern was less evident, suggesting a separation between

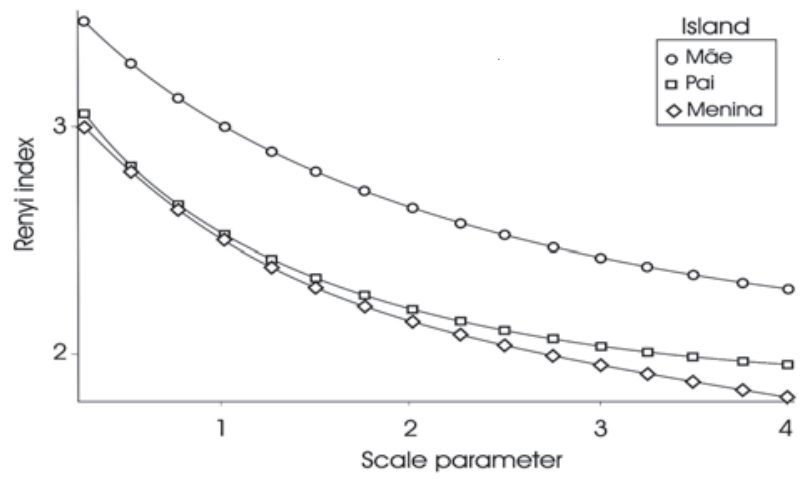

Fig. 2. Renyi's diversity ordination scale parameter comparing Menina, Mãe and Pai Islands. summer and winter samples (Fig. 3).

The two-way analysis of similarities (ANOSIM) further indicated that significant spatial differences were predominant, nevertheless with some degree of overlapping between factor levels. Pairwise tests showed that Mãe and Menina Islands were significantly different from each other. Differences between Mãe and Pai Islands and Pai and Menina Islands were less evident. Seasonal analysis was also significant, but results were less conclusive due to the high degree of overlapping between factor levels. Pairwise comparisons suggested that summer samples were significantly discernible from a pooled group of fall - spring samples (Table 3).

Results from the CCA analysis yielded a total explained variance of $15.1 \%$ at the first two canonical axes. Significant relationships between species distribution and environmental variables were restricted to four variables including bottom complexity, water temperature, percent cover of grazers and sessile constructive organisms (Fig. 4). The first canonical axis explained $8.5 \%$ of the total variance (Monte Carlo, $\mathrm{p}=$ 0.02 ) and was positively correlated with the ' $x$ ' component of

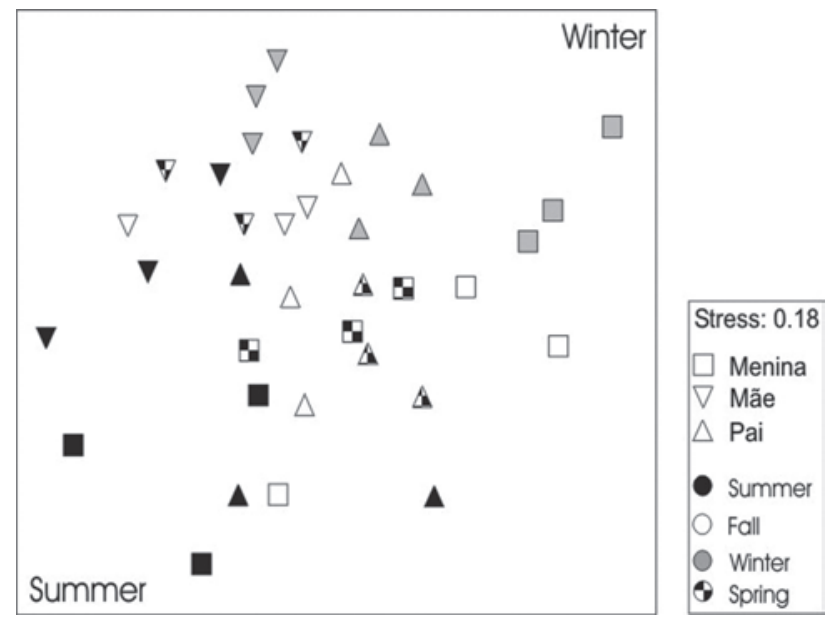

Fig. 3. Nonmetric multidimensional scale (nMDS) analysis of individual samples from Menina, Mãe and Pai Islands indicating a Summer - Winter seasonal gradient.

Table 3. Results of the two-way crossed analysis of similarity considering sites (Menina, Mãe and Pai Islands) and seasons (fall, winter, spring and summer) as the main effects.

\begin{tabular}{lcc}
\hline Factors & R Statistic & Significance \\
\hline Sites & & \\
$\quad$ Global & 0.461 & 0.001 \\
Pairwise Comparisons & & \\
$\quad$ Pai vs Mãe & 0.407 & 0.006 \\
Pai vs Menina & 0.269 & 0,011 \\
Mãe vs Menina & 0.694 & 0.001 \\
Season & & \\
$\quad$ Global R & 0.305 & 0.001 \\
Pairwise Comparisons & & \\
Fall vs Winter & 0.247 & 0.005 \\
Fall vs Spring & 0.049 & 0.347 \\
Fall vs Summer & 0.296 & 0.058 \\
Winter vs Spring & 0.370 & 0.006 \\
Winter vs Summer & 0.580 & 0.007 \\
Spring vs Summer & 0.358 & 0.012 \\
\hline
\end{tabular}


sessile constructive benthic organisms, and negatively correlated with grazers and the ' $x$ ' component of both bottom complexity and water temperature. The second axis explained $6.6 \%$ of the total variance (Monte Carlo, $\mathrm{p}=0.02$ ) and showed a negative correlation with the ' $y$ ' projection of all variables (Figs. 4 and 5).

Samples from Mãe Island were mostly separated from the other two sites in the two- dimensional canonical space, were

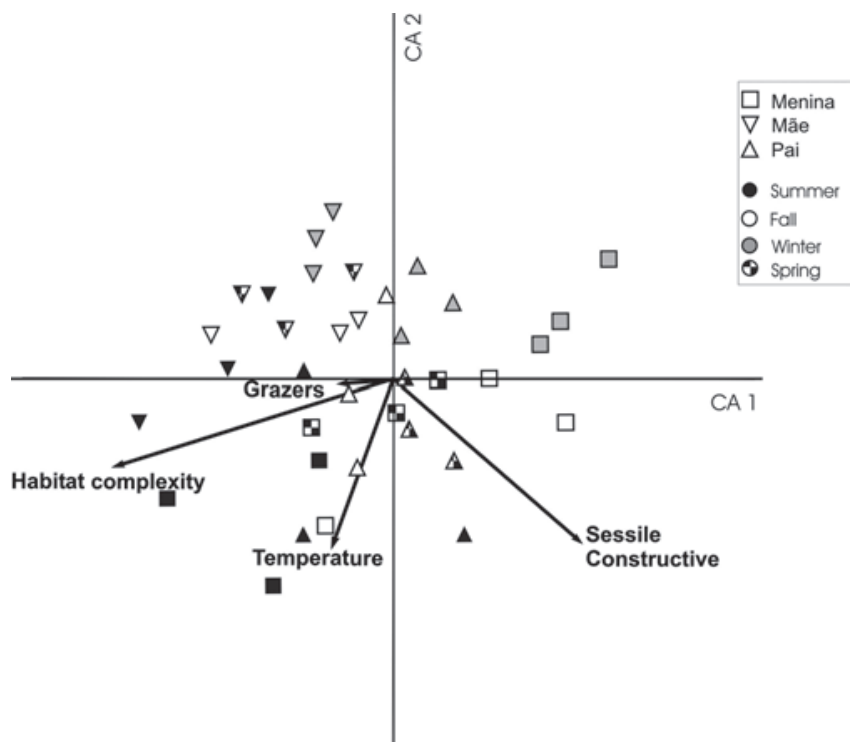

Fig. 4. Canonical Correspondence Analysis (CCA) of individual samples from Menina, Mãe and Pai Islands, indicating a Summer - Winter seasonal gradient and the correlated variables that most probably explain sample distribution in the canonical space.

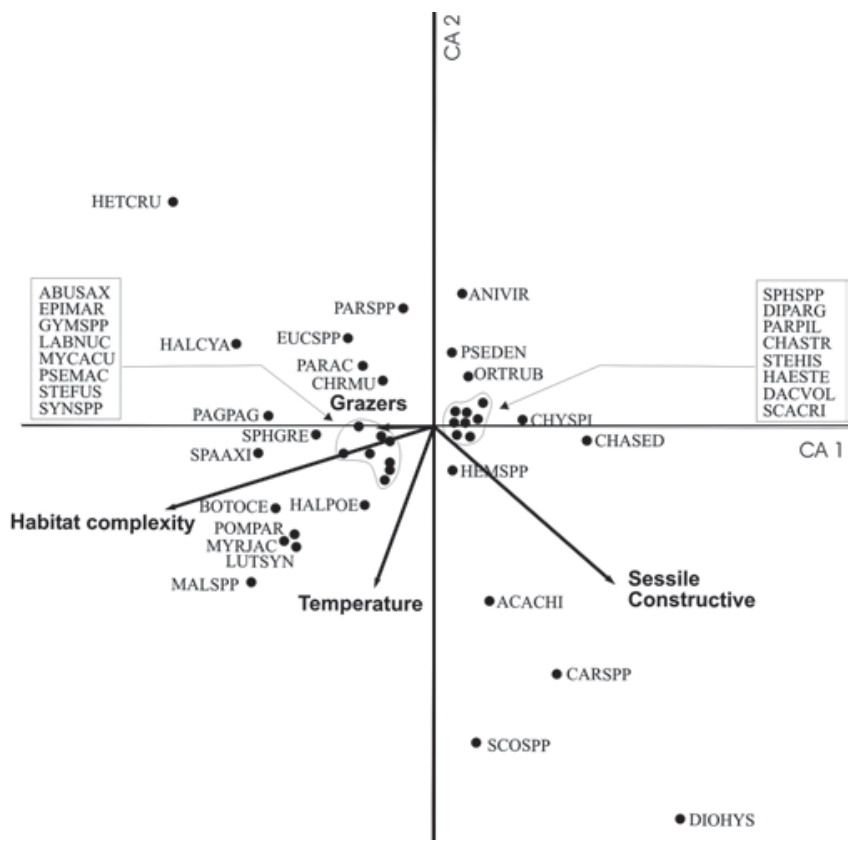

Fig. 5. Canonical Correspondence Analysis (CCA) of species and the correlated variables that most probably explain species distribution in the canonical space. negatively associated with the presence of sessile constructive organisms, and partly associated with the ' $x$ ' component of bottom complexity. Separation between samples from the Pai and Menina Island sites was less evident, but a seasonal gradient was apparent, with a tendency of winter samples to occur on the positive side of the canonical axis 2. Summer samples though followed the water temperature vector in the canonical space (Fig. 4).

Most species clustered in the middle of the diagram indicating a weak association with both principal axes. Nevertheless, Acanthurus chrirurgus, Diodon Hystrix, Caranx spp. and Scorpaena spp. were associated with spring and summer samples at Pai Island and correlated with the presence of the sessile constructive benthos. Bothus ocellatus, Pomacanthus paru, Halichoeres poeyi, Myripristis jacobus, Lutjanus synagris and Malacoctenus spp. were predominant in summer samples at Menina Island, whereas Heteropriacanthus cruentatus, Parablennius spp., Halichoeres dimidiatus, Eucinostomus spp. were mostly associated with Mãe Island samples (Fig. 5).

\section{Discussion}

Underwater censuses at Pai, Mãe and Menina Islands in Itaipu yielded a total of 42 species and 29 families. Our results suggest that our three study sites display low reef fish species diversity when compared to other sites where reef fish studies have been conducted in Brazil (e g., Floeter et al., 2001). Compared with lower latitude sites, these differences may be explained by the natural north-south latitudinal decline in species richness of reef fishes on the Brazilian coast, a consequence of regional environmental gradients and local processes (Rocha, 2003; Floeter et al., 2004). Also, due to geographic location, the studied site is potentially under the influence of water discharge from the Guanabara Bay (Mendonça Filho et al., 2003; Vilela et al., 2003). The contributions of low-salinity waters, high sediment loads, and pollution runoff derived from such a large body of water, may cause low species richness, as other authors have observed in similar habitats (Roberts \& Hawkins, 1999; Silva \& Araújo, 2003). In fact, such influences tend to be higher with strongly site-attached fish species, as most of the reef fishes are, than with species having a wider home range (Roberts \& Ormond, 1987).

The most abundant species in our study sites were representative of the coastal rocky reef fish fauna of SE Brazil (Ferreira et al., 2001; Ferreira et al., 2004; Rangel et al., 2007). Species such as Haemulon steindachneri, Orthopristis ruber and Diplodus argenteus are frequently captured by local artisanal fishers with hook and line or gill nets near the reefs (Tubino et al., 2007). The blenny, Parablennius pilicornis, was the dominant species at all sites, probably reflecting the shallow and sheltered habitat characteristics (Schofield, 2003). Nevertheless, the low density and absence of natural predators, such as groupers and large piscivores, may probably lead to a greater abundance of small bleniid fishes. Large- 
sized fishes were nearly absent from the sites, but occurred sporadically in the local artisanal fisheries landings (Tubino et al., 2007), suggesting that fishing pressure reduced their abundance in more accessible and protected sites at the islands. Floeter et al. (2006) provided evidence that fishing pressure on target species leads to unbalanced reef fish communities, with a possible reduction of top-down control mechanisms.

There are several possible factors that may determine reef fish distribution on Itaipu islands. Local differences observed among sites reflected spatial patterns and seasonal changes associated with structural complexity and species life histories. Several authors have tried to explain the structure of reef fish communities by looking at their exposure to wave energy (e.g. Williams, 1982; Russ, 1984; Galzin, 1987). Although we searched for sheltered sites with comparable hydrodynamics, our results suggested a subtle exposure gradient existed from the most exposed, Pai Island, to the least exposed, Menina Island. Wave exposure in Pai Island may produce a significant difference in the benthic composition, leading to decreased habitat complexity when compared to the other two sites.

CCA analysis further evidenced the influence of habitat complexity upon species abundance and diversity. We observed a distribution pattern with the most abundant, sighted species being grouped closer to the center of the CCA axis (e.g., Orthopritis ruber and Halichoeres poeyi), while rare, least abundant species were distributed farthest from the CCA center (e.g., Heteropriacanthus cruentatus and Diodon hystrix). Close to the CCA center, we observed the presence of two major groups, one formed by benthic invertebrate feeders (Haemulidae, Diplodus argenteus and Parablennius pilicornis), and the other by territorial herbivores (damselfishes, Stegastes fuscus) and resident predators (groupers, Epinephelus marginatus). Both groups, considered key species, greatly influence reef fish communities (Almany \& Webster, 2004). Nevertheless, their ecological role at Itaipu appears less important due to their central distribution in the canonical space. The high fishing pressure upon top predators in the area may explain, at least, the low abundance of groupers, minimizing their role as a key species in the reef fish community at the studied area.

The highest diversity was attained at Mãe Island; probably as a consequence of the greatest habitat structural complexity. Habitats with high structural complexity usually support more species and individuals by providing shelter and refuge against predation and competition (Holt, 1987; Greenberg et al., 1995; Beukers \& Jones, 1997; Connel, 1997; Charbonnel et al., 2002; Gratwicke \& Speight, 2005). Complexity appears to have a marked influence on abundance of territorial and sedentary fish species, such as damselfishes (Pomacentridae) and groupers (Serranidae) (Sale \& Douglas, 1984). Also, sheltered habitats may be a bottleneck for recruitment and growth of many reef species (Williams, 1991; Montgomery et al., 2001). The presence of large-sized rocks forming burrows and shelters at different size scales was a distinctive factor, and especially at Mãe Island, these factors are particularly important for small, site-attached fish species.

Fish fauna at Menina Island was depauperate compared with the other sites probably due to its proximity to the shore, suggesting that both intensive fishing and coastal runoff influenced fish community (Dulvy et al., 2002). Menina Island was also the most visited site by artisanal fishers and weekend divers (Mendonça-Neto, J. P. pers. observation).

Seasonal patterns were observed as a reflection of abundance and occurrence of some species throughout the year, with a clear distinction of species composition during summer and winter months. The observed seasonal tendencies were greater in species diversity during the summer months at all of the sites. This tendency may be related to the cyclic upwelling phenomena which occurs in summer months in the Brazilian southeastern region, bringing cold and nutrient-rich waters close to the coastal zone. Other studies on this region showed that plankton biomass, production and consumption were higher in summer months than in winter (Freitas \& Muelbert, 2004).

Our work showed that despite the fact that reef fish community within the Itaipu coastal zone showed similar elements, differences between sites were evident, mostly mediated by differences in the structural patterns of the rocky reefs, but also by environmental factors that vary considerably from one site to another and also throughout the year.

\section{Acknowledgments}

We thank L. Vidal and C. Barcellos for support in fieldwork and C.E.L. Ferreira and R.A. Tubino for their suggestions and critical revisions. Financial support came from Ministério da Ciência e Tecnologia - PADCT-MCT, and Fundação Carlos Chagas de Amparo a Pesquisa - FAPERJ. CAPES and CNPq provided fellowships at different levels for the authors. We are thankful to students and colleagues at the Laboratório de Biologia do Nécton e Ecologia Pesqueira ECOPESCA, Departamento de Biologia Marinha, Universidade Federal Fluminense - UFF. A. Leyva helped with English editing of the manuscript.

\section{Literature Cited}

Acosta, C. A. \& D. N. Robertson. 2002. Diversity in coral reef fish communities: the effects of habitat patchiness revisited. Marine Ecology Progress Series, 227:87-96.

Almany, G. R. \& M. S. Webster. 2004. Odd species out as predators reduce diversity of coral-reef fishes. Ecology, 85(11): 29332937.

Bellwood, D. R. \& P. C. Wainwright. 2002. The history and biogeography of fishes on coral reefs. Pp. 5-32. In: P. F. Sale (Ed.). Coral Reef Fishes: Dynamics and Diversity in a Complex Ecosystem. San Diego, Academic Press, 576 p..

Beukers, J.S. \& G. P. Jones. 1997. Habitat complexity modifies the impact of piscivores on a coral reef fish population. Oecologia, 114: 50-59. 
ter Braak, C. J. F. \& P. Smilauer. 1998. Canoco reference manual and user's guide to Canoco for Windows: software for canonical community ordination (version 4). Microcomputer Power, Ithaca, New York, USA. 110 p.

Caley, M. J. 1993. Predation, recruitment and the dynamics of communities of coral-reef fishes. Marine Biology, 117: 33-43.

Charbonnel, E., C. Serre, S. Ruitton, J. G. Harmelin \& A. Jensen. 2002. Effects of increased habitat complexity on fish assemblages associated with large artificial reef units (French Mediterranean coast). ICES Journal of Marine Science, 59: 208213.

Cheney, K. L. \& I. M. Côté. 2003. Habitat choice in adult longfin damselfish: territory characteristics and relocation times. Journal of Experimental Marine Biology and Ecology, 287: 1-12.

Clarke, K. R. \& R. M. Warwick. 1994. Similarity-based testing for community pattern: the two-way layout with no replication. Marine Biology, 118: 167-176.

Connell, S. D. 1997. The relationship between large predatory fish and recruitment and mortality of juvenile coral reef-fish on artificial reefs. Journal of Experimental Marine Biology and Ecology, 209: 261-278.

Dulvy, N. K., R. E. Mitchell, D. Watson, C. J. Sweeting \& V.C. Nicholas. 2002. Scale-dependent control of motile epifaunal community structure along a coral reef fishing gradient. Journal of Experimental Marine Biology and Ecology, 278: 1-29.

Ebeling, A. W. \& M. A. Hixon. 1991. Tropical and temperate reef fishes: comparison of community structure. Pp. 509-563. In P. F. Sale (Ed.). Coral Reef Fishes: Dynamics and Diversity in a Complex Ecosystem. San Diego, Academic Press, 576 p.

Ferreira, C. E. L, S. R. Floeter, J. L. Gasparini, J. C. Joyeux \& B. P. Ferreira. 2004. Trophic structure patterns of Brazilian reef fishes: a latitudinal comparison. Journal of Biogeography, 31: 1093-1106.

Ferreira, C. E. L., J. E. A. Gonçalves \& R. Coutinho. 2001. Community structure of fishes and habitat complexity in a tropical rocky shore. Environmental Biology of Fishes, 61: 353-369.

Ferreira, C. E. L., A. C. Peret \& R. Coutinho. 1998. Seasonal grazing rates and food processing by tropical herbivorous fishes. Journal of Fish Biology, 53: 222-235.

Floeter, S. R., C. E. L. Ferreira, A. Dominici-Arosemen \& I. R. Zalmon. 2004. Latitudinal gradients in Atlantic reef fish communities: trophic structure and spatial use patterns. Journal of Fish Biology, 64: 1680-1699.

Floeter, S. R., R. Z. P. Guimarães, L. A. Rocha, C. E. L. Ferreira, C. A. Rangel \& J. L. Gasparini. 2001. Geographic variation in reeffish assemblages along the Brazilian coast. Global Ecology and Biogeography, 10: 423-433.

Floeter, S. R., B. S. Halpern \& C. E. L. Ferreira. 2006. Effects of fishing and protection on Brazilian reef fishes. Biological Conservation, 128: 391-402.

Freitas, D. M. \& J. H. Muelbert. 2004. Ichthyoplankton distribution and abundance off southeastern and southern Brazil. Brazilian Archives of Biology and Technology, 47(4): 601-612.

Galzin, R. 1987. Structure of fish communities of French Polynesian coral reefs. I: Spatial scales. Marine Ecology Progress Series, 41: 129-136.

Gratwicke, B. \& M. R. Speight. 2005. Effects of habitat complexity on Caribbean marine fish assemblages. Marine Ecology Progress Series, 292: 301-310.

Greenberg, L. A., C. A. Paszkowski \& W. M. Tonn. 1995. Effects of prey species composition and habitat structure on foraging by two functionally distinct piscivores. Oikos, 74: 522-532.
Henderson, P. A. \& R. H. M. Seaby. 1998. Species diversity and richness, 2.3. Pisces Conservation Ltd. 117p.

Hill, M. O. 1973. Diversity and evenness: a unifying notation and its consequences. Ecology, 54: 427-473.

Holt, R. D. 1987. Prey communities in patchy environments. Oikos, 50: 276-290.

Joyeux, J. C., S. R. Floeter, C. E. L. Ferreira \& J. L. Gasparini. 2001. Biogeography of tropical reef fish: the South Atlantic puzzler. Journal of Biogeography, 28: 1-11.

Kawasaki, H., M. Sano \& T. Shibuno. 2003. The relationship between habitat physical complexity and recruitment of the coral reef damselfish, Pomacentrus amboinensis: an experimental study using small-scale artificial reefs. Ichthyology Research, 50: 73-77.

Legendre, L. \& P. Legendre. 1998. Numerical ecology, $2^{\text {nd }}$ English edition, Amsterdam, The Netherlands, Elsevier Science BV, 420p.

Luckhurst, B. E. \& K. Luckhurst. 1978. Analysis of the influence of substrate variables on coral reef fish communities. Marine Biology, 49: 317-323.

McCormick, M. I. 1989. Spatio-temporal patterns in the abundance and population structure of a large temperate reef fish. Marine Ecology Progress Series, 53: 215-225.

Mendonça Filho, J. G., T. R. Menezes, A. E. Oliveira \& M. B. Iemma. 2003. Caracterização da Contaminação por Petróleo e seus Derivados na Baía de Guanabara: Aplicação de Técnicas Organogeoquímicas e Organopetrográficas. Anuário do Instituto de Geociências (UFRJ), 26: 69-78.

Montgomery, J. C., N. Tolimieri \& O. S. Haine. 2001. Active habitat selection by pre-settlement reef fishes. Fish and Fisheries, 2: 261-277.

Parrish, J. D. 1989. Fish communities of interacting shallow-water habitats in tropical oceanic regions. Marine Ecology Progress Series, 58: 143-160.

Primer-E. 2000. PRIMER 5. Plymouth Routines in Multivariate Ecological Research. PRIMER-E Ltd, Plymouth Marine Laboratory, Plymouth, UK. 87 p.

Rangel, C. A., L. C. T., Chaves, C. Monteiro-Neto. 2007. Baseline assessment of the reef fish assemblage from Cagarras Archipelago, Rio de Janeiro, Southeastern Brazil. Brazilian Journal of Oceanography, 55(1): 7-17.

Roberts, C. M. \& J. P. Hawkins. 1999. Extinction risk in the sea. Trends in Ecology and Evolution 14(6): 241-246.

Roberts, C. M. \& R. F. G. Ormond. 1987. Habitat complexity and coral reef fish diversity and abundance on Red Sea fringing reefs. Marine Ecology Progress Series, 41: 1-8.

Rocha, L. A. 2003. Patterns of distribution and processes of speciation in Brazilian reef fishes. Journal of Biogeography, 30 : 1161-1171.

Rocha, L. A. \& I. L. Rosa. 2001. Baseline assessment of reef fish assemblages of Parcel Manuel Luiz Marine State Park, Maranhão, north-east Brazil. Journal of Fish Biology, 58: 985-998.

Rocha, L. A., I. L. Rosa \& R. S. Rosa. 1998. Peixes recifais da costa da Paraíba, Brasil. Revista Brasileira de Zoologia, 15(2): 553566.

Rosa, R. S. \& R. L. Moura. 1997. Visual assessment of reef fish community structure in the Atol das Rocas Biological Reserve, off northeastern Brazil. Proceedings of $8^{\text {th }}$ International Coral Reef Symposium 1, 983-986.

Russ, G. R. 1984. Distribution and abundance of herbivorous grazing fishes in the central Great Barrier Reef. Marine Ecology Progress Series, 20: 23-34. 
Russ, G. R. \& W. Gladstone. 1990. Accuracy and bias of visual estimates of numbers, size structure and biomass of a coral reef fish. Marine Ecology Progress Series, 64: 253-262.

Sale, P. F. 1991. The ecology of fishes on coral reefs. Academic Press: San Diego, 754p.

Sale, P. F. \& W. A. Douglas. 1984. Temporal variability in the community structure of fish on coral patch reefs and the relation of community structure to reef structure. Ecology, 65(2): 409422.

Schofield, P. J. 2003. Habitat selection of two gobies (Microgobius gulosus, Gobiosoma robustum): influence of structural complexity, competitive interactions and presence of a predator. Journal of Experimental Marine Biology and Ecology, 288: 125137.

Silva, M. A. \& F. G. Araújo. 2003. Influência das variáveis ambientais na fauna acompanhante na pesca da manjuba Anchoa tricolor (Agassiz) (Actinopterygii, Engraulidae) na Baía de Sepetiba, Rio de Janeiro. Revista Brasileira Zoologia, 20(3): 367-371.

Solow, A. R. 1993. A simple test for change in community structure. Journal of Animal Ecology, 62: 191-193.

Syms, G. \& G. P. Jones. 2000. Disturbance, habitat structure and the dynamics of a coral-reef fish community. Ecology, 81(10): 2714-2729.
Tubino, R. A., C. Monteiro-Neto, L. E. S. Moraes \& E. T. Paes. 2007. Artisanal fisheries production in the coastal zone of Itaipu, Niterói, RJ, Brazil. Brazilian Journal of Oceanography, 55(3): 187-197.

Vilela, C. G., A. E. S. Sanjinés, R. O. Ghiselli, J. G. Mendonça Filho, J. A. B. Neto \& C. F. Barbosa. 2003. Search for Bioindicators of Pollution in the Guanabara Bay: Integrations of Ecologic Patterns. Anuário do Instituto de Geociências (UFRJ), 26: 2535.

Williams, D. McB. 1982. Patterns in the distribution of fish communities across the central Great Barrier Reef. Coral Reefs, 1: 35-43.

Williams, D. McB. 1991. Patterns and processes in the distribution of coral reef fishes. Pp. 437-474. In: P. F. Sale (Ed.). The Ecology of Fishes on Coral Reefs. San Diego, Academic Press. 576p.

Accepted April 2008 Published June 28, 2008 